Vít ŠT'ASTNÝ*

\title{
The Continuity and Discontinuity of the Titles of Supreme State Organs in the European Countries of the Communist Bloc with special attention to the Situation in Czechoslovakia
}

The following contribution deals with the development of the titles of supreme state organs (i.e. heads of state) in European countries during the communist era with respect to the differences between these countries. The head of state is considered to be a symbol representing the state in relation to other countries and often functions as a living symbol of the unity of the state.

Central European, South-Eastern and Eastern European countries with communist regimes would change the organ that served as head of state. These changes were motivated in some cases by the fact that monarchy had been deposed and replaced by the republic, but the countries that had been republics before the communist coups d'état changed their supreme organs, as well. The value of discontinuity was this way reinforced by titular or symbolic discontinuity.

All the so-called Eastern Bloc countries (the Soviet Union and its satellites) used to be republics (monarchy is by definition precluded in such countries). Nevertheless, most of these countries refused the traditional concept that the head of the republic should be the President of the Republic. Although, some of them (mostly only for a limited period) were represented by the President of the Republic, most of these countries in accordance with the principle of collective leadership replaced the individual President by collective organs such as the titular head of state (the chairman of this collective organ was regarded as the head of the republic). However, despite the proclaimed principle of collective leadership, political life was organized on the basis of the leader principle. The Secretary General or First Secretary of the Communist Party (the Head of the Communist Party) was positioned on top of the pyramid. The Head of the Communist Party functioned sometimes as a head of state, sometimes as a head of government, but there was no common rule: the practice varied in different countries. Despite the specific practices in different Eastern Bloc countries, there were some common features. The basic common feature was the collectivity of the organ that served as head of state (if presidency had been abolished). The abolition of presidency often ensued after the death of the incumbent president or after the adoption of a new constitution.

Before the description of the historical situation in Eastern Bloc countries, let me engage in a brief summary about the respective situation in our current world. Most of contemporary republics favour a constitutional system, in which the President of the

* Researcher, Institute of State and Law, Academy of Sciences of the Czech Republic, 11600 Praha 1, Národní 18.

E-mail: stastny@ilaw.cas.cz 
Republic functions as the head. Out of 194 independent states, 45 states are monarchies, 149 are republics. The head of the monarchy is the Emperor (Japan), the King or Queen (Belgium, Denmark, the Netherlands, Norway, Spain, Sweden, the United Kingdom and other 15 countries of the Commonwealth, ${ }^{1}$ Bahrain, Bhutan, Jordan, Cambodia, Malaysia, Saudi Arabia, Thailand, Lesotho, Morocco, Swaziland, Samoa, Tonga), the Grand Duke (Luxembourg), the Prince (Monaco, Liechtenstein) or two Co-Princes, respectively (Andorra), the Sultan (Brunei, Oman), the Emir (Qatar, Kuwait), the Pope (The Vatican). The United Arab Emirates constitute a monarchy, a federation of seven federal emirates (these emirates are monarchies), however, the head of all federations is the President. The remaining 149 countries are republics. The President is the head in 142 countries (if we include the United Arab Emirates, the President is the head of state in 143 countries). Seven other republics, where the President is not the head of state, include Bosnia and Herzegovina (collective presidency with 3 members and a rotating chairman), San Marino (two CaptainsRegent), Burma (Chairman of the National Council for Peace and Development), Niger (Chairman of the Supreme Council for the Restoration of Democracy), Cuba (President of the Council of State), North Korea and Libya, where it is questionable who the head of state is. ${ }^{2}$

At present, therefore, the titles of the President of the Republic and the head of state don't overlap in merely seven republics. The number of republics where the President of the Republic doesn't coincide with the head of state decreased after the collapse of communist regimes in Central, South-Eastern and Eastern Europe. In these countries, the characteristic collective state leadership without an individual President used to be common.

In Poland after World War II, presidency was restored in 1947. However, this post was abolished in accordance with the July Constitution of 1952, which copied the soviet model. Between 1952 and 1989, the Council of State functioned as the collective head of state of Poland. Following the Polish Round Table Agreement in 1989, the Council of State was abolished and its Chairman (Jaruzelski) became President of the Republic for a transitional period. Simultaneously, the Government of the Republic of Poland in Exile also prevailed and it was headed by the President of the Republic (1939-1990). That secured the continuity with the Polish Republic before World War II. The last president in exile was Ryszard Kaczorowski, who resigned upon the election of Lech Wałęsa as President of the Republic of Poland in 1990. The ninety-year-old Kaczorowski died in April 2010 during the air crash near Smolensk.

The situation in the German Democratic Republic was similar to that in Poland. Although the GDR was a newly established republic under soviet control, its head was President of the Republic. Nevertheless, after the death of Wilhelm Pieck, the first president

1 Antigua and Barbuda, the Bahamas, Barbados, Belize, Grenada, Jamaica, Canada, Saint Lucia, Saint Kitts and Nevis, Saint Vincent and the Grenadines, Australia, New Zealand, Papua New Guinea, Solomon Islands, Tuvalu.

2 The chairmanship of the National Defence Commission of North Korea (Kim Jong-il as chairman) was elevated by the amended constitution to the rank of "the highest post in the state." Nonetheless, traditional duties of the head of state are largely performed by the Chairman of the Standing Committee of the People's Supreme Assembly. In addition, the deceased long-life president, Kim Il-sung was declared eternal president. In Libya, the de facto leader is the Leader of the Revolution Gaddafi, but the titular Head of State is the General Secretary of the People's General Congress. 
(1960), the presidency was abolished and the Council of State as a new collective organ serving as head of state was set up in the GDR. This constitutional situation prevailed until the end of the GDR in 1990.

In Hungary, presidency had existed until 1949 when in accordance with the new constitution it was replaced by the collective Presidential Council of the Hungarian People's Republic. The incumbent President became its first chairman. However, individual presidency was restored after the collapse of the communist regime in Hungary.

In Romania, after the coerced abdication of King Michael I and the abolition of monarchy, the Chairman of the Presidium of the National Grand Assembly functioned as head of state. This status changed in 1961, afterwards the Chairman of the Council of State served as head of state. The next change ensued in 1974, when the ambitious Romanian communist leader, Ceauşescu proclaimed himself President. In communist Romania, the tendency was opposed to that in other communist countries, since a collective head of state was replaced by an individual President.

In Bulgaria, subsequently to the abolition of monarchy, the departure of Tsar Simeon II to exile and the provisional presidency of Vasil Petrov Kolarov (1946-1947), in accordance with new constitution a titular head of state, i.e. the Chairman of the Presidium of the National Assembly was in office. After 1971, when next new constitution was adopted, the Council of State (with the chairman at the top) functioned as a collective head of state. This constitutional situation prevailed until the collapse of the communist regime in Bulgaria.

In Yugoslavia, President Tito (before 1953 he had served as the Prime Minister) functioned as head of state. After Tito's death individual presidency was abolished and the Collective Presidency (with its rotating heads as representatives of the Yugoslav nations) functioned as head of state. The individual presidency was restored in 1992, but by that time the original Yugoslavia had already dissolved.

During the entire communist period, the titular head of Albania was the Chairman of the Presidium of the People's Assembly. Presidency was restored in 1991.

Finally, it was the situation in the Soviet Union, its constitutional and state system with its Stalinist constitution dating back to 1936 that were models for its satellites. From 1938, the titular head was the State Chairman of the Presidium of the Supreme Soviet (between 1989 and 1990 only Chairman of the Supreme Soviet). The first and the last President of the Soviet Union, that is, Gorbachev was elected in 1990.

In the second part of this article, I will describe the respective situation in communist Czechoslovakia. This situation was specific. The head of the Czech state from its formation had been the Prince, then the King. Since the end of the monarchy and the establishment of the Czechoslovak Republic, the head has been the President of the Republic. This presidential tradition was not disrupted either in the era of communism. In contrast to other Eastern Bloc countries, the individual president in Czechoslovakia has never been replaced by a collective organ.

The position of the President of Czechoslovakia (and of the Czech Republic at the moment) is peculiar not only from a constitutional, but also from political and sociological points of view. The President of the Republic enjoys full public confidence and the majesty of the position is accented by some (not only legal) circumstances, such as his seat is in the majestic Prague Castle, which is the largest coherent castle complex in the world, furthermore, his portraits are on display in schools, offices and other public spaces despite the lack of a relevant legal obligation. He is the only living person with portraits on post 
stamps, finally, the President is welcomed by ceremonious fanfares signalling his arrival during official actions.

The Czech presidential tradition was created by Masaryk, the first Czechoslovak president and his successors have always followed in his footsteps. We can cite a definitive historical publication that outlines the dominant view on President Masaryk: "The first president, T. G. Masaryk with his extensive education in philosophy, history and sociology, knowledge of foreign countries and languages, with important scientific and educational activities, significant political experience and exquisite personal morality has created a standard of statesmanship in Czech political culture and thereby has become an unattainable ideal for his successors". ${ }^{3}$

In some respects, Masaryk followed the monarchical traditions of the Czech lands. He was called "tatíček"-daddy (good father of the nation). This concept was partially transferred to his successors. This is important as to understanding the developments after the communist coup.

The presidential tradition in the Czech lands was not disrupted even during World War II, since besides Beneš, the president in exile, the so-called state president Hácha was in office in the Nazi-controlled Protectorates of Bohemia and Moravia.

After the communist coup d'état in February 1948 (formally perpetrated in accordance with constitution), the incumbent democratic president, Beneš remained in office (in accordance with communist interests, since the legitimacy of the new regime was thereby strengthened). After President Beneš' abdication (four months later), a new president, Gottwald, the leader of the Communist Party and Prime Minister was elected. The constitution of 1948 had been prepared before the communist coup and many legal institutions (including individual presidency) originated in the constitution of the first republic. Therefore, communist leadership benefited from the prestigious and popular post of the presidency.

After Gottwald's death in 1953, the abolishment of the post of the President of the Republic became possible. The issue was discussed in leading organs of the Communist Party of Czechoslovakia, but the according proposals were rejected, since obviously, the Communist Regime intended to draw on the popularity of the presidential post. Relevant discussions resuscitated during the preparation of the new constitution in 1960, nevertheless, the establishment of a new collective head of state was rejected again. Although, the new so-called Socialist Constitution copied soviet models, the name of the country (Czechoslovak Socialist Republic) changed and consequently, the national emblem was also replaced, whereas, the post of the President of the Republic was retained. This constitutional situation did not change until the end of the Czechoslovak communist era in 1989.

The post of the President of the Republic used to be largely ceremonial, but its importance increased, since the head of the Communist Party was often elected to be President. Communist leaders considered this post to be a symbolic confirmation of their leading role in the country.

Let me mention one example from 1975. Seriously ill President Svoboda refused to abdicate, therefore the Parliament adopted a special constitutional amendment. This act stated that the Parliament (the Federal Assembly) was authorised to elect a new president provided that the incumbent one was unable to carry out his official duties for a year or even longer. In Svoboda's case, his bad health made the act relevant. Immediately after the

3 Čapka, F.: Dějiny zemí Koruny české v datech. Prague, 1998, 622 (translation by the author). 
adoption of this amendment, the Secretary General of the Communist Party of Czechoslovakia, Husák was elected new president, although except for symbolic power, he acquired no real power.

Subsequently, the presidential tradition with its symbolic importance has continued undisrupted in the Czech Republic. 